\title{
PENGARUH LINGKUNGAN BAHASA TERHADAP KEMAMPUAN BERBICARA BAHASA ARAB
}

\author{
Baiq Tuhfatul Unsi \\ Institut Agam Islam Bani Fattah Jombang, Indonesia \\ baiqtuhfatulunsi@gmail.com
}

\begin{abstract}
Language is a habit that is easy to control and master. Language becomes part of human behavior which is shaped and influenced by the surrounding environment. speaking skills aim to make students able to communicate verbally properly and naturally with the language they are learning. Dulay explained that the language environment is very important for a learner to be successful in learning a new language (a second language). The focus of this study was to determine the effect of the language environment on students' speaking ability in Arabic. The research method used is a quantitative method. The results of this study are: 1. The Arabic language environment at MTs Salafiyah Syafi'iyah Tebuireng Jombang is quite good with a percentage of $66.88 \%$. 2. The ability to speak Arabic for grade VIII students of MTs Salafiyah Syafi'iyah Tebuireng Jombang is quite good with a percentage of $59.2 \%$. 3. There is a significant influence between the language environment on the ability to speak Arabic. With the value of $\mathrm{T}$ count $=$ 3.812 greater than $\mathrm{T}$ table $=2,000$ and the probability value (a) $0.000<0.05$, then $\mathrm{Ho}$ is rejected and $\mathrm{Ha}$ is accepted. This means that the language environment is very influential on the speaking ability of students of Mts Salafiyah Syafi'iyah Tebuireng Jombang.
\end{abstract}

Keyword: Language environment, Speaking ability 


\section{Pendahuluan}

Berbicara merupakan kegiatan berbahasa yang aktif dari seorang pemakai bahasa yang menuntut prakarsa nyata dalam penggunaan bahasa untuk mengungkapkan diri secara lisan. Dalam pengertian ini berbicara merupakan bagian dari kemampuan bahasa yang aktif produktif. Sebagai bagian dari kemampuan berbahasa yang aktif dan produktif, kemampuan berbicara menuntut penguasaan terhadap beberapa aspek dan kaidah penggunaan bahasa. ${ }^{1}$

Secara umum keterampilan berbicara bertujuan agar para pelajar mampu berkomunikasi lisan secara baik dan wajar dengan bahasa yang mereka pelajari, maksudnya menyampaikan pesan kepada orang lain dalam cara yang secara social dapat diterima, sebagaimana dikatakan oleh Subyakto. $^{2}$ Namun tentu saja untuk mencapai tahap kepandaian berkomunikasi diperlukan aktivitas-aktivitas latihan yang memadai dan mendukung. Aktivitas-aktivitas seperti itu bukan perkara mudah bagi pembelajaran bahasa, sebab harus tercipta dahulu lingkungan bahasa yang mengarahkan para pelajar kepada pengembangan keterampilan berbicara.

Dulay menerangkan, bahwa lingkungan bahasa sangat penting bagi seorang pembelajar untuk dapat berhasil dalam mempelajari bahasa baru (bahasa kedua). ${ }^{3}$ Sejalan dengan hal ini Para penganjur pendekatan linguistik kontrastif berpendirian bahwa penguasaan suatu bahasa tidak lain dari pembentukan kebiasaan-kebiasaan. Oleh karena itu untuk dapat menguasai bahasa kedua jalan yang paling tepat adalah dengan latihan yang terus menerus, tanpa henti, sehingga pada suatu saat akan terbentuk kebiasaan-kebiasaan seperti yang telah terjadi ketika mempelajari bahasa pertama. ${ }^{4}$

Tokoh-tokoh pendidikan masa lampau berpandangan bahwa factor lingkungan sangat bermakna dan dijadikan sebagai landasan dalam mengembangkan konsep pendidikan dan pengajaran. Seperti J.J. Rousseau dengan teorinya "kembali ke alam" menunjukkan betapa pentingnya pengaruh alam terhadap perkembangan anak didik. Karena itu pendidikan anak harus dilaksanakan di lingkungan alam yang bersih,

\footnotetext{
1 Abdul Wahab Rosyidi. Media Pembelajaran Bahasa Arab (Malang : UIN Maliki Press. 2009), 65.

2 Acep Hermawan, metodologi Pembelajaran Babasa Arab (Bandung : PT. Remaja Rosdakarya, 2011), 136.

${ }^{3}$ Abdul Chaer, Psikososiolinguistik Kajian Teoritik (Jakarta : PT Rineka Cipta, 2009), 257258.

4 Abdul Chaer dan Leoni Agustina, Sosiolinguitik Perkenalan Awal (Jakarta : PT Rineka Cipta, 2004), 219.
} 
tenang, suasana menyenangkan, dan segar, sehingga sang anak tumbuh sebagai manusia yang baik. ${ }^{5}$

MTs Salafiyah Syafi'iyah merupakan sekolah formal yang berada dibawah naungan Pesantren Tebuireng. Guna mendukung pembelajaran bahasa khususnya berbahasa Arab aktif, MTs Salafiyah Syafi'iyah berusaha menciptakan lingkungan berbahasa Arab dengan langkah memberikan metode Muba>dathah. Peran Lembaga dan para tenaga pengajar juga sangat mendukung berjalannya program kebahasaan sehingga pembelajaran bahasa Arab berjalan dengan baik. Kualitas Lingkungan bahasa Arab yang telah tercipta selain menjadi sumber dan motivasi belajar juga menjadi aset dan kebanggaan MTs Salafiyah Syafi'iyah dalam menunjukkan citra positif dan keunggulan kualitasnya.

\section{Kajian Teori}

Kaum behavioris memandang bahwa bahasa adalah kebiasaan yang mudah dicontrol dan dikuasai. Bahasa menjadi bagian dari tingkah laku manusia yang dibentuk dan dipengaruhi oleh lingkungan sekitarnya. Dalam hal ini, unsur-unsur yang paling asasi di lingkungan adalah kedua orang tuanya, para pendidik atau guru, saudara-saudaranya, temantemannya. Lingkungan ini bisa pula berbentuk lingkungan pendidikan, seperti lingkungan seorang siswa asing yang belajar bahasa sasaran. ${ }^{6}$

Sedemikian pentingnya kualitas lingkungan pembelajaran itu, sehingga Nabi Muhammad saw. mengilustrasikan bahwa lingkungan keluarga itu dapat merubah keyakinan dan agama seorang anak yang dibesarkan dalam keluarga. Sabda Nabi saw.: "Setiap anak dilabirkan dalam keadaan fitrah. Kedua orang tuanyalah (lingkungan keluarga) yang kemudian menjadikan anak itu beragama Yabudi, Nashrani, atau Majusi....."(HR Muslim) ${ }^{7}$

Krashen $^{8}$ membagi lingkungan pembelajaran bahasa menjadi dua, lingkungan formal dan informal. Lingkungan formal, mencakup berbagai aspek pendidikan formal dan non formal, dan sebagian besar berada di dalam kelas atau laboratorium. Apakah lingkungan formal ini memberikan masukan kepada pembelajar berupa sistem bahasa (pengetahuan unsur-unsur bahasa) atau wacana bahasa (keterampilan berbahasa), tergantung kepada tipe pembelajaran atau metode yang

\footnotetext{
${ }^{5}$ Oemar Hamalik, Proses Belajar Mengajar ( Jakarta : PT. Bumi Aksara, 2005), 194.

${ }^{6}$ Abdul Aziz bin Ibrahim el-Ushaili. Psikolinguistik Pembelajaran Bahasa Arab (Bandung : Humaniora 2009), 47.

${ }^{7}$ Muhbib Abdul Wahab, Epistimologi dan Metodologi Pembelajaran Babasa Arab (Jakarta : UIN Jakarta. 2008), 292.

8 Ahmad Fuad Efendy, Metodologi Pengajaran Bahasa Arab (Malang : Misykat, 2005), 165166.
} 
digunakan oleh pengajar. Namun terdapat kecenderungan bahwa lingkungan formal memberikan lebih banyak sistem bahasa dari pada wacana bahasa. Lingkungan informal memberikan pajanan komunikasi yang alamiyah, dan sebagian besar berada di luar kelas. Oleh karena itu lingkungan informal ini memberikan lebih banyak wacana bahasa dari pada sistem bahasa.

Sejalan dengan hal ini Ellis ${ }^{9}$ menyebutkan adanya dua tipe pembelajaran bahasa yaitu: pertama. tipe naturalistic, bersifat alamiah, tanpa guru, dan tanpa kesengajaan. Pembelajaran berlangsung di dalam lingkungan kehidupan masyarakat. Kedua. tipe formal, berlangsung di dalam kelas dengan guru, materi, dan alat bantu belajar yang sudah dipersiapkan.

Kemampuan Berbicara/ speaking skill adalah kemampuan untuk mengungkapkan bunyi-bunyi artikulasi atau kata-kata untuk mengekspresikan pikiran berupa ide, pendapat, keinginan, atau perasaan kepada mitra bicara. ${ }^{10}$

Penekanan yang harus diberikan ketika melaksanakan pengajaran bahasa melalui kegiatan berbicara adalah efektivitas. Keefektifan dalam berbicara terlihat jelas dalam kecekatan dan kecepatan mengutarakan buah pikiran dan perasaan, serta ketepatan dalam memilih kosakata dan kalimat yang sangat menarik. Salah satu cara latihan yang dianggap efektif untuk dapat mencapai kemampuan berbahasa lisan dari hal yang paling sederhana hingga hal-hal yang rumit adalah berlatih menggunakan pola kalimat. ${ }^{11}$

Sejumlah penelitian menunjukkan bahwa ada hubungan antara lingkungan bahasa dengan kemampuan berbahasa kedua. Krasen menyimpulkan bahwa lingkungan bahasa formal dan informal mempengaruhi kemampuan berbahasa asing dengan cara yang berbeda. Lingkungan informal memberikan masukan bagi perolehan, sedangkan lingkungan formal menyediakan masukan bagi monitor. Teori monitor yang dikemukakan oleh Krasen ini bisa menjelaskan beberapa fenomena ${ }^{12}$ belajar bahasa asing. Uraian di muka menunjukkan betapa pentingnya factor lingkungan bahasa dalam menanamkan kemampuan

\footnotetext{
${ }_{9}$ Abdul Chaer, Psikososiolinguistik Kajian Teoritik (Jakarta : Rineka Cipta, 2009), 243.

10 Acep Hermawan, Metodologi Pembelajaran Bahasa Arab (Bandung : PT Remaja Rosdakarya Offset, 2011), 135.

11 Ahmad Izzan. Metodologi Pembelajaran Bahasa Arab (Bandung : Humaniora. 2011), 138.

12 Misalnya, mengapa para siswa pondok pesantren yang diberi kesempatan banyak untuk terlibat langsung dalam penggunaan bahasa Arab, cenderung lebih lancar berbicara dari pada siswa pondok pesantren yang berkonsentrasi pada pendalaman nahwu-sharaf.
} 
berbahasa, karena lingkungan bahasa merupakan wahana pemerolehan bahasa bagi siswa. ${ }^{13}$

\section{Metode Penelitian}

Metode penelitian ini menggunakan metode kuantitatif, data dinyatakan dengan angka dan dianalisis dengan teknik statistik Adapun Populasi dalam penelitian ini yaitu berjumlah 237 siswa kelas VIII MTs Salafiyah Syafi'iyah Tebuireng Jombang. Sedangkan sampel dalam penelitian ini berjumlah 50 siswa dengan mengambil $20 \%$ dari keseluruhan jumlah populasi yang ada.

Suharsimi Arikunto menyatakan bahwa batas ukuran kecil besarnya sampel adalah tiga puluh. Tiga puluh atau kurang dikatakan sampel kecil, sedangkan tiga puluh atau lebih dikatakan sampel besar. Dan jika anggota subjek dalam populasi berkisar 100 sampai 150 orang dan dalam pengumpulan datanya menggunakan angket, maka seluruh subjek tersebut dapat diambil sebagai sampel seluruhnya. Sedangkan jika subjek dalam populasi terdiri lebih dari 150, maka sampel yang digunakan sekitar $25 \%-30 \%$ nya saja. ${ }^{14}$

Adapun susunan instrument penelitian dari variabel dan jabarannya yang menjadikan berbagai indikator adalah sebagai berikut:

Tabel 1

Rincian Variabel

\begin{tabular}{|c|c|c|}
\hline Variabel & Sub variabel & Indikator \\
\hline \multirow[t]{4}{*}{$\begin{array}{l}\text { Lingkungan } \\
\text { Bahasa }\end{array}$} & \multirow{4}{*}{$\begin{array}{l}\text { Segala hal yang } \\
\text { di dengar dan } \\
\text { dilihat oleh } \\
\text { pembelajar } \\
\text { terkait dengan } \\
\text { bahasa kedua } \\
\text { yang dipelajari. }\end{array}$} & $\begin{array}{l}\text { - Lingkungan yang telah } \\
\text { disetting sebagai sumber } \\
\text { belajar siswa. }\end{array}$ \\
\hline & & $\begin{array}{l}\text { Lingkungan yang } \\
\text { mendorong anak untuk } \\
\text { selalu berbahasa Arab. }\end{array}$ \\
\hline & & $\begin{array}{l}\text { - Sarana dan situasi yang } \\
\text { mendukung siswa untuk } \\
\text { berbahasa Arab Aktif. }\end{array}$ \\
\hline & & $\begin{array}{lr}\text { - Lingkungan } & \text { yang } \\
\text { memberikan } & \text { pengaruh } \\
\text { yang bersifat } & \text { mendidik } \\
\text { bagi siswa. } & \end{array}$ \\
\hline
\end{tabular}

\footnotetext{
13 Ahmad Fuad Efendi, Metodologi Pengajaran Bahasa Arab (Malang : Misykat. 2005), 165.

14 Suharsimi Arikunto, Manajement Penelitian (Jakarta: PT. Rineka Cipta. 2009), 95.
} 


\begin{tabular}{|c|c|c|}
\hline & & 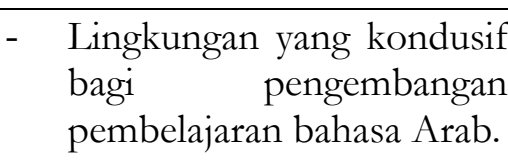 \\
\hline \multirow[t]{8}{*}{$\begin{array}{l}\text { Kemampuan } \\
\text { berbicara }\end{array}$} & $\begin{array}{l}\text { Siswa } \\
\text { berbicara } \\
\text { banyak }\end{array}$ & 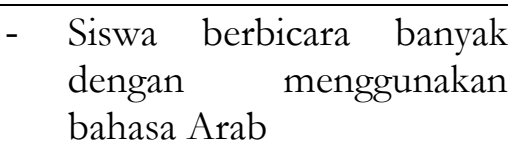 \\
\hline & \multirow[t]{3}{*}{$\begin{array}{l}\text { Partisipasi aktif } \\
\text { dari siswa }\end{array}$} & $\begin{array}{l}\text { - Siswa bertanya kepada } \\
\text { guru dengan berbahasa } \\
\text { Arab }\end{array}$ \\
\hline & & $\begin{array}{ll}\text { - } & \text { Siswa menjawab } \\
\text { pertanyaan yang diajukan } \\
\text { guru dengan berbahasa } \\
\text { Arab }\end{array}$ \\
\hline & & $\begin{array}{l}\text { - } \begin{array}{l}\text { Siswa menanggapi materi } \\
\text { yang diajarkan dengan } \\
\text { berbahasa Arab }\end{array} \\
\end{array}$ \\
\hline & \multirow[t]{2}{*}{$\begin{array}{l}\text { Memiliki } \\
\text { motivasi tinggi }\end{array}$} & $\begin{array}{lll}\text { - } & \text { Siswa disiplin dalam } \\
\text { pembelajaran bahasa Arab }\end{array}$ \\
\hline & & $\begin{array}{l}\text { - } \begin{array}{l}\text { Siswa mematuhi apa yang } \\
\text { diperintahkan guru }\end{array} \\
\text { a }\end{array}$ \\
\hline & \multirow{2}{*}{$\begin{array}{l}\text { Bahasa yang } \\
\text { dipakai adalah } \\
\text { bahasa yang } \\
\text { diterima }\end{array}$} & $\begin{array}{lll}\text { - } & \text { Siswa menggunakan } \\
\text { kosakata yang } & \text { diberikan } \\
\text { dalam berbicara }\end{array}$ \\
\hline & & 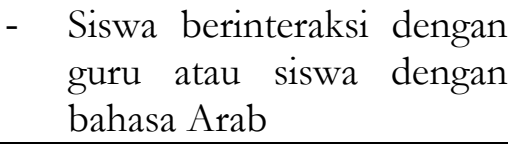 \\
\hline
\end{tabular}

Dari berbagai indikator di atas dijadikan sebagai bahan dasar pertanyaan pada angket yang diberikan kepada responden.Angket yang dijadikan sebagai pengumpulan data menggunakan skala likert. Skala likert ini dijadikan sebagai pengukur terhadap variabel yang dijabarkan dalam indikator variabel tersebut kemudian dijadikan sebagai bahan pertanyaan dalam angket.

Jawaban setiap item instrument yang menggunakan skala likert mempunyai gradasi dari sangat positif sampai sangat negative. Skala likert yang digunakan dalam angket ini berbentuk pilihan ganda yang memiliki skor yang telah ditentukan juga oleh peneliti. 
Dalam instrument penelitian ini, digunakan angket Favorable dan Unfavoreble untuk mengukur pertanyaan, dengan nilai adalah sebagai berikut:

Tabel 2

\begin{tabular}{|c|c|c|}
\multicolumn{3}{|c}{ Pedoman nilai $^{15}$} \\
\hline Jawaban & Favoreble & Unfavoreble \\
\hline Selalu & 4 & 1 \\
\hline Sering & 3 & 2 \\
\hline Kadang-kadang & 2 & 3 \\
\hline Tidak pernah & 1 & 4 \\
\hline
\end{tabular}

\section{Pembahasan}

\section{Deskripsi data}

Setelah mengetahui bahwa semua soal (14 butir) dinyatakan 12 soal valid dan reliable, maka peneliti kemudian menyebarkan angket kepada 50 responden di MTs Salafiyah Syafi'iyah Tebuireng Jombang dengan perincian sebagai berikut :

1. Lingkungan Bahasa

Tabel 3

Lingkungan Bahasa

\begin{tabular}{|c|c|c|c|}
\hline & \multicolumn{3}{|c|}{$\begin{array}{l}\text { Apakah guru anda memotivasi anda untuk selalu } \\
\text { berbahasa Arab di Sekolah? }\end{array}$} \\
\hline & Jawaban & Frekuensi & Persen $\%$ \\
\hline 1. & Selalu & 30 & 60 \\
\hline 2. & Sering & 18 & 36 \\
\hline 3. & Kadang-kadang & 2 & 4 \\
\hline 4. & Tidak Pernah & 0 & 0 \\
\hline \multirow[t]{2}{*}{2} & \multicolumn{3}{|c|}{$\begin{array}{l}\text { Apakah lingkungan sekolah anda menekankan untuk } \\
\text { berbicara bahasa Arab? }\end{array}$} \\
\hline & Jawaban & Frekuensi & Persen $\%$ \\
\hline 1. & Selalu & 33 & 66 \\
\hline 2. & Sering & 9 & 18 \\
\hline 3. & Kadang-kadang & 5 & 10 \\
\hline 4. & Tidak Pernah & 3 & 6 \\
\hline 3 & \multicolumn{3}{|c|}{$\begin{array}{l}\text { Apakah anda berbicara bahasa Arab } \\
\text { lingkungan sekolah? }\end{array}$} \\
\hline
\end{tabular}

${ }^{15}$ Sugiyono, Metode Penelitian Pendidikan Pendekatan Kuantitatif Kualitatif dan R\&D (Bandung: Alfabeta, 2008), 93. 


\begin{tabular}{|c|c|c|c|}
\hline & Jawaban & Frekuensi & Persen $\%$ \\
\hline 1. & Selalu & 0 & 0 \\
\hline 2. & Sering & 6 & 12 \\
\hline 3. & Kadang-kadang & 42 & 84 \\
\hline 4. & Tidak Pernah & 2 & 4 \\
\hline \multirow{3}{*}{4} & $\begin{array}{l}\text { Apakah guru anda menggunakan bahasa Arab ketika di } \\
\text { sekolah? }\end{array}$ \\
\cline { 2 - 4 } & Jawaban & Frekuensi & Persen $\%$ \\
\hline 1. & Selalu & 14 & 28 \\
\hline 2. & Sering & 25 & 50 \\
\hline 3. & Kadang-kadang & 11 & 22 \\
\hline 4. & Tidak Pernah & 0 & 0 \\
\hline \multirow{2}{*}{5} & $\begin{array}{l}\text { Apakah guru anda mengajar dengan } \\
\text { bahasa Arab? }\end{array}$ & menggunakan \\
\cline { 2 - 4 } & Jawaban & Frekuensi & Persen $\%$ \\
\hline 1. & Selalu & 0 & 0 \\
\hline 2. & Sering & 21 & 42 \\
\hline 3. & Kadang-kadang & 27 & 54 \\
\hline 4. & Tidak Pernah & 2 & 4 \\
\hline
\end{tabular}

\begin{tabular}{|c|c|c|c|}
\hline \multirow[t]{2}{*}{6} & \multicolumn{3}{|c|}{$\begin{array}{l}\text { Apakah anda berbahasa Arab di luar lingkungan } \\
\text { sekolah? }\end{array}$} \\
\hline & Jawaban & Frekuensi & Persen $\%$ \\
\hline 1. & Selalu & 0 & 0 \\
\hline 2. & Sering & 0 & 0 \\
\hline 3. & Kadang-kadang & 40 & 80 \\
\hline 4. & Tidak Pernah & 10 & 20 \\
\hline \multirow{2}{*}{7} & \multicolumn{3}{|c|}{ Apakah sekolah anda menerapkan hari bahasa Arab? } \\
\hline & Jawaban & Frekuensi & Persen $\%$ \\
\hline 1. & Selalu & 38 & 76 \\
\hline 2. & Sering & 10 & 20 \\
\hline 3. & Kadang-kadang & 0 & 0 \\
\hline 4. & Tidak Pernah & 2 & 4 \\
\hline \multirow[t]{2}{*}{8} & \multicolumn{3}{|c|}{$\begin{array}{l}\text { Apakah anda mendapat hukuman ketika tidak berbicara } \\
\text { bahasa Arab? }\end{array}$} \\
\hline & Jawaban & Frekuensi & Persen $\%$ \\
\hline 1. & Selalu & 10 & 20 \\
\hline
\end{tabular}




\begin{tabular}{|c|c|c|c|}
\hline 2. & Sering & 9 & 18 \\
\hline 3. & Kadang-kadang & 20 & 40 \\
\hline 4. & Tidak Pernah & 11 & 22 \\
\hline \multirow[t]{2}{*}{9} & \multicolumn{3}{|c|}{$\begin{array}{l}\text { Apakah guru anda berbicara bahasa Arab dengan guru } \\
\text { lain ketika di sekolah? }\end{array}$} \\
\hline & Jawaban & Frekuensi & Persen $\%$ \\
\hline 1. & Selalu & 17 & 34 \\
\hline 2. & Sering & 20 & 40 \\
\hline 3. & Kadang-kadang & 13 & 26 \\
\hline 4. & Tidak Pernah & 0 & 0 \\
\hline \multirow[t]{2}{*}{10} & \multicolumn{3}{|c|}{$\begin{array}{l}\text { Apakah anda berbicara dengan teman menggunakar } \\
\text { bahasa Indonesia ketika di sekolah? }\end{array}$} \\
\hline & Jawaban & Frekuensi & Persen $\%$ \\
\hline 1. & Selalu & 0 & 0 \\
\hline 2. & Sering & 23 & 46 \\
\hline 3. & Kadang-kadang & 19 & 38 \\
\hline 4. & Tidak Pernah & 8 & 16 \\
\hline \multirow[t]{2}{*}{11} & \multicolumn{3}{|c|}{$\begin{array}{l}\text { Apakah anda berbahasa Arab ketika kegiatan belaja } \\
\text { mengajar di sekolah? }\end{array}$} \\
\hline & Jawaban & Frekuensi & Persen $\%$ \\
\hline 1. & Selalu & 1 & 2 \\
\hline 2. & Sering & 8 & 16 \\
\hline 3. & Kadang-kadang & 35 & 70 \\
\hline 4. & Tidak Pernah & 6 & 12 \\
\hline \multirow[t]{2}{*}{12} & \multicolumn{3}{|c|}{$\begin{array}{l}\text { Apakah guru anda memberikan kosakata bag } \\
\text { pengembangan bahasa Arab di sekolah? }\end{array}$} \\
\hline & Jawaban & Frekuensi & Persen $\%$ \\
\hline 1. & Selalu & 34 & 68 \\
\hline 2. & Sering & 14 & 28 \\
\hline 3. & Kadang-kadang & 1 & 2 \\
\hline 4. & Tidak Pernah & 1 & 2 \\
\hline
\end{tabular}

Dari hasil analisis data tentang pengaruh kualitas lingkungan bahasa MTs Salafiyah Syafi'iyah Tebuireng Jombang di atas secara keseluruhan dapat diketahui bahwa jumlah nilai/skor akhir adalah 1672 
dan dari nilai/skor akhir tersebut, selanjutnya dicari nilai meannya dengan menggunakan rumus formulasi mean sebagai berikut:

$$
\begin{aligned}
& M=\frac{\sum x}{N} \\
& M=\frac{1672}{50} \\
& M=33,44
\end{aligned}
$$

Setelah diketahui bahwa jumlah rata-rata setiap responden adalah 33,44 (F), sedang jumlah maksimal atau nilai/skor idealnya adalah $50(\mathrm{~N})$, maka jumlah prosentase tentang lingkungan Bahasa Arab siswa MTs Salafiyah syafi'iyah kelas VIII Tebuireng Jombang adalah dihitung dengan menggunakan rumus berikut:

$$
\begin{aligned}
& \mathrm{P}=\frac{\mathrm{F}}{\mathrm{N}} \times 100 \% \\
& \mathrm{P}=\frac{33,44}{50} \times 100 \% \\
& \mathrm{P}=66,88
\end{aligned}
$$

Dari hasil diatas, apabila dikonsultasikan dengan patokan standart sebagaimana disebutkan di atas, maka kualitas lingkungan Bahasa Arab siswa MTs Salafiyah syafi'iyah kelas VIII Tebuireng Jombang tergolong cukup baik.

Sedangkan untuk menganalisa hasil perhitungan rumus diatas, maka peneliti berpedoman pada kriteria yang dikatakan oleh Suharsimi Arikunto:

1. $76 \%-100 \%$ tergolong baik

2. $56 \%-75 \%$ tergolong cukup baik

3. $40 \%-55 \%$ tergolong kurang baik

4. Kurang dari $40 \%$ tergolong sangat kurang baik.

\section{Kemampuan Berbicara Bahasa Arab}

Tabel 4

Kemampuan Berbicara Bahasa Arab

\begin{tabular}{|c|c|c|c|}
\hline \multirow{2}{*}{1} & \multicolumn{3}{|c|}{ Apakah anda mampu berbicara bahasa Arab? } \\
\cline { 2 - 4 } & Jawaban & Frekuensi & Persen\% \\
\hline 1. & Selalu & 3 & 6 \\
\hline 2. & Sering & 23 & 46 \\
\hline 3. & Kadang-kadang & 24 & 48 \\
\hline 4. & Tidak Pernah & 0 & 0 \\
\hline \multirow{2}{*}{2} & $\begin{array}{l}\text { Apakah anda memahami pembicaraan bahasa Arab } \\
\text { teman anda dengan baik? }\end{array}$ \\
\cline { 2 - 4 } & Jawaban & Frekuensi & Persen $\%$ \\
\hline
\end{tabular}




\begin{tabular}{|c|c|c|c|}
\hline 1. & Selalu & 5 & 10 \\
\hline 2. & Sering & 24 & 48 \\
\hline 3. & Kadang-kadang & 20 & 40 \\
\hline 4. & Tidak Pernah & 1 & 2 \\
\hline \multirow{2}{*}{3} & \multicolumn{3}{|c|}{ Apakah anda lancar berbicara dengan bahasa Arab? } \\
\hline & Jawaban & Frekuensi & Persen $\%$ \\
\hline 1. & Selalu & 1 & 2 \\
\hline 2. & Sering & 15 & 30 \\
\hline 3. & Kadang-kadang & 33 & 66 \\
\hline 4. & Tidak Pernah & 1 & 2 \\
\hline \multirow[t]{2}{*}{4} & \multicolumn{3}{|c|}{$\begin{array}{c}\text { Apakah anda bertanya kepada guru menggunakan } \\
\text { bahasa Arab? }\end{array}$} \\
\hline & Jawaban & Frekuensi & Persen $\%$ \\
\hline 1. & Selalu & 1 & 2 \\
\hline 2. & Sering & 14 & 28 \\
\hline 3. & Kadang-kadang & 31 & 62 \\
\hline 4. & Tidak Pernah & 4 & 8 \\
\hline \multirow[t]{2}{*}{5} & \multicolumn{3}{|c|}{$\begin{array}{c}\text { Apakah anda dapat menjawab pertanyaan guru dengan } \\
\text { bahasa Arab? }\end{array}$} \\
\hline & Jawaban & Frekuensi & Persen $\%$ \\
\hline 1. & Selalu & 1 & 2 \\
\hline 2. & Sering & 14 & 28 \\
\hline 3. & Kadang-kadang & 33 & 66 \\
\hline 4. & Tidak Pernah & 2 & 4 \\
\hline \multirow[t]{2}{*}{6} & \multicolumn{3}{|c|}{$\begin{array}{c}\text { Apakah anda berbicara dengan teman menggunakan } \\
\text { bahasa Arab? }\end{array}$} \\
\hline & Jawaban & Frekuensi & Persen $\%$ \\
\hline 1. & Selalu & 0 & 0 \\
\hline 2. & Sering & 9 & 18 \\
\hline 3. & Kadang-kadang & 39 & 78 \\
\hline 4. & Tidak Pernah & 2 & 4 \\
\hline \multirow[t]{2}{*}{7} & \multicolumn{3}{|c|}{$\begin{array}{c}\text { Apakah anda diam ketika guru mengajukan pertanyaan } \\
\text { dengan bahasa Arab? }\end{array}$} \\
\hline & Jawaban & Frekuensi & Persen $\%$ \\
\hline 1. & Selalu & 8 & 16 \\
\hline 2. & Sering & 32 & 64 \\
\hline 3. & Kadang-kadang & 8 & 16 \\
\hline 4. & Tidak Pernah & 2 & 4 \\
\hline 8 & \multicolumn{3}{|c|}{ Apakah anda dapat berdiskusi dengan menggunakan } \\
\hline
\end{tabular}




\begin{tabular}{|c|c|c|c|}
\hline & \multicolumn{3}{|c|}{ bahasa Arab? } \\
\hline & Jawaban & Frekuensi & Persen \% \\
\hline 1. & Selalu & 1 & 2 \\
\hline 2. & Sering & 0 & 0 \\
\hline 3. & Kadang-kadang & 32 & 64 \\
\hline 4. & Tidak Pernah & 17 & 34 \\
\hline \multirow[t]{2}{*}{9} & \multicolumn{3}{|c|}{$\begin{array}{l}\text { Apakah anda berbicara bahasa Arab dengan } \\
\text { menggunakan kosakata yang diberikan guru? }\end{array}$} \\
\hline & Jawaban & Frekuensi & Persen $\%$ \\
\hline 1. & Selalu & 9 & 18 \\
\hline 2. & Sering & 25 & 50 \\
\hline 3. & Kadang-kadang & 15 & 30 \\
\hline 4. & Tidak Pernah & 1 & 2 \\
\hline \multirow{2}{*}{10} & \multicolumn{3}{|c|}{ Apakah anda kesulitan dalam berbicara bahasa Arab? } \\
\hline & Jawaban & Frekuensi & Persen $\%$ \\
\hline 1. & Selalu & 6 & 12 \\
\hline 2. & Sering & 29 & 56 \\
\hline 3. & Kadang-kadang & 13 & 26 \\
\hline 4. & Tidak Pernah & 2 & 4 \\
\hline \multirow[t]{2}{*}{11} & \multicolumn{3}{|c|}{$\begin{array}{c}\text { Apakah anda dapat menanggapi materi pelajaran } \\
\text { dengan berbahasa Arab? }\end{array}$} \\
\hline & Jawaban & Frekuensi & Persen $\%$ \\
\hline 1. & Selalu & 10 & 20 \\
\hline 2. & Sering & 19 & 38 \\
\hline 3. & Kadang-kadang & 18 & 36 \\
\hline 4. & Tidak Pernah & 3 & 6 \\
\hline \multirow[t]{2}{*}{12} & \multicolumn{3}{|c|}{$\begin{array}{c}\text { Apakah anda berbicara banyak dengan tanpa } \\
\text { menggunakan bahasa Arab? }\end{array}$} \\
\hline & Jawaban & Frekuensi & Persen $\%$ \\
\hline 1. & Selalu & 1 & 2 \\
\hline 2. & Sering & 27 & 54 \\
\hline 3. & Kadang-kadang & 14 & 28 \\
\hline 4. & Tidak Pernah & 8 & 16 \\
\hline
\end{tabular}

Dari hasil analisis data tentang kemampuan Berbicara Bahasa Arab MTs Salafiyah Syafi'iyah Tebuireng Jombang di atas secara keseluruhan 
dapat diketahui bahwa jumlah nilai/skor akhir adalah 1480 dan dari nilai/skor akhir tersebut, selanjutnya dicari nilai meannya dengan menggunakan rumus formulasi mean.

Setelah diketahui bahwa jumlah rata-rata setiap responden adalah 29,6 (F), sedang jumlah maksimal atau nilai/skor idealnya adalah $50(\mathrm{~N})$, maka jumlah prosentase tentang kemampuan Berbicara Bahasa Arab siswa MTs Salafiyah syafi'iyah kelas VIII Tebuireng Jombang adalah dihitung dengan menggunakan rumus berikut:

$$
\begin{aligned}
& P=\frac{F}{N} \times 100 \% \\
& P=\frac{29,6}{50} \times 100 \% \\
& P=59,2
\end{aligned}
$$

Dari hasil diatas, apabila dikonsultasikan dengan patokan standart sebagaimana disebutkan di atas, maka kemampuan Berbicara Bahasa Arab siswa MTs Salafiyah syafi'iyah kelas VIII tergolong cukup baik.

\section{a. Uji Hipotesis}

Untuk menjawab hipotesis yang dikemukakan di muka adalah dengan menggunakan linier sederhana, dibantu dengan program SPSS 16.0 for windows. Berdasarkan hasil regresi dari data primer yang diolah dengan menggunakan SPSS 16.0 didapatkan hasil pengujian sebagai berikut :

Untuk mengetahui besar pengaruh masing-masing variabel $\mathrm{X}$ terhadap variabel Y, maka didapatkan hasil sebagai berikut :

\section{Uji secara Parsial (Uji T)}

Hasil uji hipotesis secara parsial merupakan pengujian hipotesis antara setiap variabel bebas secara sendiri-sendiri terhadap variabel terikat. Penulis kemukakan bahwa jikalau nilai $\mathrm{T}$ hitung $>\mathrm{T}$ tabel dan nilai probabilitas $<5 \%$ atau 0,05 dengan begitu secara parsial menunjukkan variabel bebas secara sendiri-sendiri berpengaruh terhadap

\begin{tabular}{|c|c|c|c|c|c|c|}
\hline & \multirow[t]{2}{*}{ Model } & \multicolumn{2}{|c|}{$\begin{array}{c}\text { Unstandardized } \\
\text { Coefficients }\end{array}$} & \multirow{2}{*}{$\begin{array}{c}\text { Standardized } \\
\text { Coefficients } \\
\text { Beta }\end{array}$} & \multirow[t]{2}{*}{$\mathrm{t}$} & \multirow{2}{*}{ Sig. } \\
\hline & & B & Std. Error & & & \\
\hline \multirow[t]{2}{*}{1} & (Constant) & 1.736 & 5.523 & & .314 & .755 \\
\hline & X.TOTAL & .477 & .125 & .463 & 3.812 & .000 \\
\hline & & & & & & \\
\hline
\end{tabular}
variabel terikat.

Tabel 5 
Dari tabel di atas didapatkan persamaan regresi sederhana sebagai berikut : $\mathrm{Y}=\mathrm{a}+\mathrm{bX}$. Untuk membuktikan ada atau tidaknya pengaruh variabel X terhadap Variabel Y yang signifikan. Hal ini dibuktikan pada koefisien regresi dari nilai $\mathrm{T}$ didapatkan hasil perhitungan hipotesis $\mathrm{t}_{\text {hitung }}$ dibandingkan dengan $\mathrm{t}_{\text {tabel }}$ dengan standart signifikan $5 \%$ dan df: $\mathrm{n}-2=$ $50-2=48$ maka diperoleh $t_{\text {tabel }}=2,000$. Dengan ketentuan sebagai berikut :

$$
\text { Terima Ha : jika } t_{\text {hitung }}>t_{\text {tabel }}
$$

Adapun hipotesis adalah Pengaruh variabel Lingkungan Babasa (X) terhadap Kemampuan berbicara bahasa Arab (Y).

$$
\mathrm{Y}=1.736+477 \mathrm{X}_{1}
$$

Hasil persamaan regresi linier dari hasil output uji parsial (t) diperoleh nilai $\mathrm{T}_{\text {hitung }}=3,812$ menunjukkan $\mathrm{T}_{\text {hitung }}>\mathrm{T}_{\text {tabel }}$ yaitu 2,000 dengan demikian karena $\mathrm{T}_{\text {hitung }}=3,812$ lebih besar dari $\mathrm{T}_{\text {tabel }}=2,000$ dan nilai probabilitas (a) $0,000<0,05$ maka Ho ditolak dan Ha diterima, maka nilai koefisien regresi pengarub Lingkungan Bahasa signifikan, dan terdapat pengaruh yang signifikan dalam pengaruh Lingkungan Bahasa terhadap kemampuan berbicara bahasa Arab di MTs Salafiyah Syafi'iyah Tebuireng Jombang.

\section{b. Analisa Pembahasan}

Dulay menerangkan, bahwa lingkungan bahasa sangat penting bagi seorang pembelajar untuk dapat berhasil dalam mempelajari bahasa baru (bahasa kedua). ${ }^{16}$ Sejalan dengan hal ini Para penganjur pendekatan linguistik kontrastif berpendirian bahwa penguasaan suatu bahasa tidak lain dari pembentukan kebiasaan-kebiasaan. Oleh karena itu untuk dapat menguasai bahasa kedua jalan yang paling tepat adalah dengan latihan yang terus menerus, tanpa henti, sehingga pada suatu saat akan terbentuk kebiasaan-kebiasaan seperti yang telah terjadi ketika mempelajari bahasa pertama. ${ }^{17}$

Tokoh-tokoh pendidikan masa lampau berpandangan bahwa factor lingkungan sangat bermakna dan dijadikan sebagai landasan dalam

\footnotetext{
16 Abdul Chaer, Psikososiolinguistik Kajian Teoritik ( Jakarta : PT Rineka Cipta, 2009), 257258.

${ }^{17}$ Abdul Chaer dan Leoni Agustina, Sosiolinguitik Perkenalan Awal (Jakarta : PT Rineka Cipta, 2004), 219.
} 
mengembangkan konsep pendidikan dan pengajaran. Misalnya J.J. Rousseau dengan teorinya "kembali ke alam" menunjukkan betapa pentingnya pengaruh alam terhadap perkembangan anak didik. Karena itu pendidikan anak harus dilaksanakan di lingkungan alam yang bersih, tenang, suasana menyenangkan, dan segar, sehingga sang anak tumbuh sebagai manusia yang baik. ${ }^{18}$

Teori diatas sejalan dengan hasil penelitian dengan uji parsial yaitu terdapat pengaruh yang signifikan antara lingkungan bahasa terhadap kemampuan berbicara. Dengan nilai $\mathrm{T}_{\text {hitung }}=3,812$ menunjukkan $\mathrm{T}_{\text {hitung }}$ $>\mathrm{T}_{\text {tabel }}$ yaitu 2,000 dengan demikian karena $\mathrm{T}_{\text {hitung }}=3,812$ lebih besar dari $\mathrm{T}_{\text {tabel }}=2,000$ dan nilai probabilitas (a) $0,000<0,05$ maka Ho ditolak dan Ha diterima. Dalam hal ini bahwa pengaruh kualitas lingkungan bahasa memiliki tingkat yang cukup baik dengan prosentase $66,88 \%$.

Hal ini berarti teori yang telah diangkat dalam penelitian ini sesuai dan berlaku di lapangan. Penelitian ini menunjukkan adanya hubungan yang berarti atau signifikan dalam penelitian ini.

\section{Kesimpulan}

Dari penelitian di atas dapat disimpulkan sebagai berikut :

Lingkungan bahasa Arab di MTs Salafiyah Syafi'iyah Tebuireng Jombang tergolong cukup baik dengan prosentase 66,88\%. Artinya kualitas lingkungan bahasa di MTs Salafiyah Syafi'iyah sudah tergolong cukup baik karena sesuai dengan teori yang telah dipaparkan di atas.

Kemampuan berbicara Bahasa Arab siswa kelas VIII MTs Salafiyah Syafi'iyah Tebuireng Jombang tergolong cukup baik dengan prosentase 59,2\%. Artinya Kemampuan berbicara Bahasa Arab siswa MTs Salafiyah Syafi'iyah sudah tergolong cukup baik karena sesuai dengan teori yang telah dipaparkan di atas.

Terdapat pengaruh yang signifikan antara lingkungan bahasa terhadap kemampuan berbicara bahasa Arab. Dengan nilai $\mathrm{T}_{\text {hitung }}=$ 3,812 lebih besar dari $\mathrm{T}_{\text {tabel }}=2,000$ dan nilai probabilitas (a) $0,000<$ 0,05 maka Ho ditolak dan Ha diterima. Artinya lingkungan bahasa sangat berpengaruh terhadap kemampuan berbicara siswa Mts Salafiyah Syafi'iyah Tebuireng Jombang.

18 Oemar Hamalik, Proses Belajar Mengajar (Jakarta : PT. Bumi Aksara, 2005), 194. 


\section{Daftar Pustaka}

Abdul Aziz bin Ibrahim el-Ushaili. Psikolinguistik Pembelajaran Babasa Arab. Bandung: Humaniora, 2009

Abdul Chaer, Psikososiolinguistik Kajian Teoritik. Jakarta: PT Rineka Cipta, 2009

Abdul Chaer dan Leoni Agustina, Sosiolinguitik Perkenalan Awal. Jakarta: PT Rineka Cipta, 2004.

Abdul Wahab Rosyidi. Media Pembelajaran Bahasa Arab. Malang: UIN Maliki Press, 2009.

Acep Hermawan, Metodologi Pembelajaran Bahasa Arab. Bandung: PT. Remaja Rosdakarya, 2011.

Ahmad Fuad Efendy, Metodologi Pengajaran Bahasa Arab. Malang: Misykat, 2005.

Ahmad Izzan. Metodologi Pembelajaran Bahasa Arab. Bandung: Humaniora. 2011.

Oemar Hamalik, Proses Belajar Mengajar. Jakarta: PT. Bumi Aksara, 2005.

Muhbib Abdul Wahab, Epistimologi dan Metodologi Pembelajaran Bahasa Arab. Jakarta: UIN Jakarta. 2008.

Suharsimi Arikunto, Manajement Penelitian. Jakarta: PT. Rineka Cipta. 2009.

Sugiyono, Metode Penelitian Pendidikan Pendekatan Kuantitatif Kualitatif dan R\&DD. Bandung: Alfabeta, 2008. 